\title{
WASTAGE IN PRIMARY EDUCATION: DROPOUT AND REPETITION AT PRIMARY
} SCHOOLS IN PALPA DISTRICT

Department of Geography Education Tribhuvan University, Kirtipur rijalshibaprasad@hotmail.com

\begin{abstract}
The study aimed at analyzing wastage in primary education focusing on dropout and grade repetition in primary level and is limited to the case of Palpa district. The study is based on School Mapping Database of District Education Office, Palpa, 2009. Primary education in Palpa district is characterized by high rate of dropout (9.7 percent) and grade repetition (14.6 percent). This indicates the low efficiency and high educational wastage. The scenario of dropout and repetition is not uniform across the district and varies sharply by resource centers. The high wastage in primary education in Palpa district clearly indicates the great challenge in achieving the goal of universal primary education the 'quality basic education for all'. Failure in examination, poverty and ignorance of the parents are the main reasons for a high repetition. In many instances, especially, poor and dalit children left the schools after the distribution of scholarships and get enrolled again next year hopping the same. Likewise, failure in examination, poverty and ignorance of parents and cultural factors are responsible for high dropout.
\end{abstract}

Key words: Access, dropout, literacy, repetition, school-age children, strategy, wastage.

\section{The Context}

'Universal primary education' is a Millennium Development Goal of the United Nations, declared in September 2000. The target of declaration is to "ensure that, by 2015, children elsewhere, boys and girls alike, will be able to complete a full course of primary schooling" (United Nations, 2008). The Dakar Framework for Action has re-affirmed education as fundamental human right and underlined the importance of right-based government action in implementing 'Education for All' at the national level (Tomasevski, 2004). In order to meet the target of the Millennium Development Goal, Nepal is committed and has adopted the 'Education for All' strategy and a National Plan of Action (EFA 2001-2015) since 2001 (DOE, 2009) declaring free, compulsory and accessible primary education to every child of primary school age.

Considering the present day needs of education in the global context, the government of Nepal has made various interventions and launched different programs with a view to improving access and quality of education. As a result, there has been a remarkable improvement in the educational attainment of both men and women over the years in Nepal with a steady improvement in the overall literacy rates (Government of Nepal, 2006; ). However, Nepal has faced several challenges in educational development. Poor quality and low efficiency are the crucial problems of these challenges (CERID, 2001). The low efficiency rate in primary education is causing huge national resource wastage hindering the effort of achieving quality basic education for all. The education sector receives a large share of public expenditure at present.

The wastage in education refers to failure of a system to provide universal education, failure to recruit and hold children into system, failure to set appropriate objectives and inefficiency in the achievement of objectives (Brimer, and Pauli 1971). Raising enrolment, maintaining stability and reducing the dropout rate is the key to universal primary education. Unfortunately, high dropout rates and grade repetition are two major symptoms of educational wastage which seriously affect Education for All goals and also the key impediments to increasing educational access and attainment. High repetitions are often correlated with high dropouts (Eiseman, 1997).

The issue of dropout and grade repetition is of major concern given the goal of universal primary education. Studies have showed the low efficiency rate of primary education in Nepal. This is mainly due to high rate of grade repetition and dropout (CERID, 2001). Karki (2009) concluded that the high dropout in primary 
education was causing low efficiency and 'huge wastage' in primary education. Likewise, Acharya, (2007) showed an alarming rate of dropout and repetition especially of dalits in primary schools in Nepal. Present paper is an attempt along similar lines, to analyze the status of dropout and grade repetition in primary education, focusing on the case of Palpa District, Nepal.

\section{Methods and Materials}

The study is primarily based on quantitative data, collected from the District Education Office (DEO), Palpa, during 2009. Dropout and grade repetition data were acquired from the School Mapping Database DEO, Palpa. Published and unpublished sources including official documents were also used. Relevant qualitative information was gathered from formal and informal discussions with school supervisors (SS) and resource persons (RPs) during field visit.

The individual school level data were grouped and calculated by Resource Center (RC). For this, DEO's division of RC is followed. With a view of monitoring school level educational activities, the DEO, Palpa has divided Palpa district into 18 RCs, one RC consisting 2 to 5 local administrative units- village development committees and municipalities (Table 1). Wastage in education is measured analyzing present status of dropout and grade repetition in primary grades. The analysis of dropout is limited to event dropout. The event dropout is the percentage of students that dropout in a single year without completing a level or grade. Likewise, the status of grade repetition is also analyzed using single year data.

Table 1: Distribution of VDCs and Municipalities by Resource Center

\begin{tabular}{|l|l|}
\hline Resource center & VDCs/Municipalities \\
\hline Argali & Argali, Khyaha, and Siddheswar (3) \\
\hline Aryabhanjyang & $\begin{array}{l}\text { Chidipani, Khanichhap, Nayarnamtales, Pipaldanda and Pokharathok } \\
(5)\end{array}$ \\
\hline Bhairabsthan & Bhairabsthan, Bandipokhara, Deurali and Khasyouli (4) \\
\hline Chappani & Chhapani, Barangdi, Darlamdanda, Khanigaon and Yamgha (5) \\
\hline Chhara & Chhara, Bhuwanpokhari, Mujhung and Somadi (4) \\
\hline Dovan & Dovan and Kachal (2) \\
\hline Gadakot & Gadakot, Sahalkot and Wakamalang (3) \\
\hline Hungi & Hungi, Foksingkot and Gejha (3) \\
\hline Jhadewa & Jhadewa, Bahadurpur, Gothadi and Rahabas (4) \\
\hline Kaseni & Kaseni, Madanpokhara and Rupse (3) \\
\hline Kusumkhola & Kushumkhola, Fek, Palungmainadi and Timure (4) \\
\hline Masyam & Masyam, Koldada and Telgha (3) \\
\hline Mityal & Mityal, Archale, Galdha and Jhirubas (4) \\
\hline Rampur & Rampur, Darchha, Khaliban and Siluwa (4) \\
\hline Rigneraha & Rigneraha, Birkot, Jalpa and Jyamire (4) \\
\hline Satyawati & Satyawati, Baldengadhi and Juthapauwa (3) \\
\hline Tahu & Tahu, Devinagar, Heklang and Humin (4) \\
\hline Tansen & $\begin{array}{l}\text { Tansen N. P, Bodha Pokharathok, Boudha Gumba and } \\
\text { Chirtungdhara (4) }\end{array}$ \\
\hline
\end{tabular}




\section{The Study Area}

Palpa District has a diverse topography and climate. It covers an area of 1,373 square kilometres and lies in the mid-hills in the Western Development Region of Nepal (Figure $1)$. The district is divided into 66 local administrative units (65 village development committees (VDCs) and one municipality) and 18 Resource Centers (RCs).

According to the population census 2001, the district has 49,942 households and a total population of 268,558 (125,068 male and 143,490 female). Average family size in the district was 5.38. Population density was 196 persons per
Altogether 66.2 percent of the population of 6 years and above was literate. Male literacy was high (76.2 percent) as compared to female literacy (57.8 percent). The literacy level of Janajati and Dalits was even lower, at 44 percent and 42 percent respectively (DEO, 2009). The literacy status was higher in urban areas as compared to the rural ones. There were altogether 493 schools running primary grades in the district. The total number of student enrolled in primary grades was 60,598 in 2009. Per school enrolment was 124 persons. In terms of the Human Development Index, Palpa ranked 23 out of 75 districts of Nepal in 2004. The Human Poverty Index of the district was 33, which is higher than the national average (39.6) (UNDP, 2004).

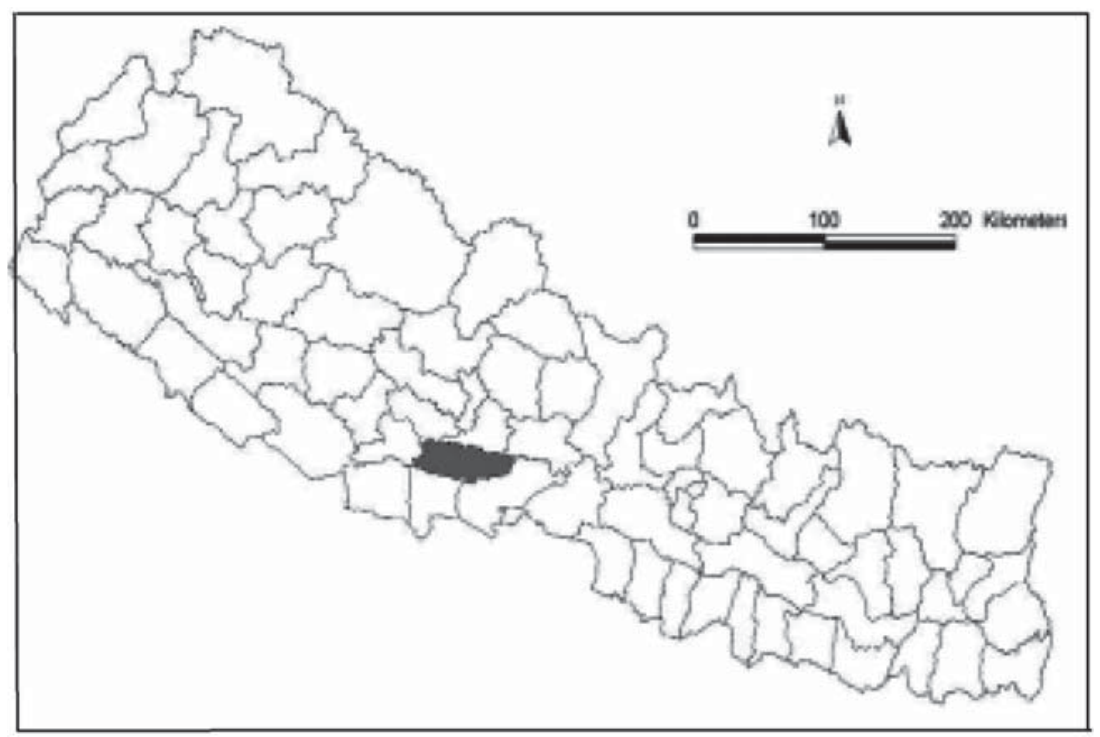

Figure 1: Location of Palpa District: The Study Area

square kilometer, with a growth rate of 1.28 percent per annum. The population of the district is composed of different caste/ethnic groups, with the numerical domination of Magars (50.92 percent). Brahmin (19.25 percent), Chhetri (8.05 percent), Kami (5.82 percent) and Newar (3.61 percent) are the other main caste/ ethnic groups of the district. The proportion of the population speaking Nepali as their mother language was 61 percent, with nearly 34 percent speaking the Magar language. Nearly 80 percent of the population was 5-59 years of age, with 12.4 percent below 5 years and 7.8 percent 60 years and above.

\section{Discussion and Findings}

The discussion on educational wastage concentrates mainly on dropout and grade repetition. However, in this context, the analysis of enrollment and promotion is equally crucial. This section deals with these aspects.

Primary level total enrolment, the number of students who presented at and passed the final exam by resource centre (RC) is shown in Table 2. Altogether 60,168 students were enrolled in 493 schools running primary grades in Palpa District in 2009. Of these, 90.3 percent took the final examination and the rest 9.7 percent left the school without taking it. The total number of 
Table 2: Enrolment, Exam Appear and Grade Promotion by RC, 2009

\begin{tabular}{|l|c|c|c|c|c|}
\hline \multirow{2}{*}{ RC } & \multirow{2}{*}{ Enrolment } & \multicolumn{2}{|c|}{ Took Exam } & \multicolumn{2}{c|}{ Passed } \\
\cline { 3 - 6 } & Number & \% of enrolment & Number & \% of enrolment \\
\hline Argali & 2570 & 2458 & 95.6 & 1848 & 71.9 \\
\hline Aryabhanjyang & 3441 & 3084 & 89.6 & 2533 & 73.6 \\
\hline Bhairabsthan & 1753 & 1571 & 89.6 & 1187 & 67.7 \\
\hline Chappani & 3017 & 2616 & 86.7 & 2095 & 69.4 \\
\hline Chhara & 4157 & 3765 & 90.6 & 2724 & 65.5 \\
\hline Dovan & 2604 & 2275 & 87.4 & 1716 & 65.9 \\
\hline Gadakot & 2824 & 2363 & 83.7 & 1787 & 63.3 \\
\hline Hungi & 3304 & 2807 & 85.0 & 2134 & 64.6 \\
\hline Jhadewa & 3005 & 2693 & 89.6 & 2029 & 67.5 \\
\hline Kaseni & 2940 & 2701 & 91.9 & 2230 & 75.9 \\
\hline Kusumkhola & 2605 & 2482 & 95.3 & 1772 & 68.0 \\
\hline Masyam & 2403 & 2169 & 90.3 & 1822 & 75.8 \\
\hline Mityal & 4306 & 3833 & 89.0 & 3071 & 71.3 \\
\hline Rampur & 6557 & 6063 & 92.5 & 5162 & 78.7 \\
\hline Rigneraha & 3994 & 3510 & 87.9 & 2998 & 75.1 \\
\hline Satyawati & 1830 & 1749 & 95.6 & 1639 & 89.6 \\
\hline Tahu & 2974 & 2764 & 92.9 & 2173 & 73.1 \\
\hline Tansen & 5884 & 5412 & 92.0 & 5064 & 86.1 \\
\hline Total & 60168 & 54315 & 90.3 & 44583 & 74.1 \\
\hline Source: $D E O$ & & & & & \\
\hline
\end{tabular}

Source: DEO Palpa, 2009

students promoted to the next grade was 74.1 percent of the total enrolment in the district.

The proportion of students that appered at the examination varies across the district. The proportion of students that took it was high in Argali and Satyawati RCs. More than 95 percent of the total students from these RCs took their final examination. Gadakot (83.7 percent) showed the worse situation among all of the RCs. Likewise, a sharp variation exists across the district in terms of proportion of student succeeding in the final examination. The situation of Satyawati was comparatively the best of all in terms of the proportion of students that passed the final examination. About 90 percent of the students passed the final examination from this resource center. Gadakot showed the worst situation in terms of proportion of students succeeding in the final examination. Only 63.3 percent of the total enrolment completed the grade from this RC.

Dropout is perhaps the most critical form of wastage (UNESCO, 1984). It represents a staggering loss. UNESCO (1984) considers 'dropout rate' as one of the ways measuring educational wastage. Dropping out from school is a serious problem that affects not only the individual student's future, but also the wider society as well as the nation at large. Raising the stable enrolment rate and reducing the dropout rate is the key to a successful universal primary education programme. Dropout means leaving school or the educational programme prematurely. According to GAO (2002), someone who leaves school or college without finishing their course of study is a dropout. And the dropout rate is the percentage of students enrolled in a given grade in an academic year who are not enrolled in any grade during the following school year (DOE, 2008). There exist multiple ways of analyzing dropouts- event rate, status rate and cohort dropout rate (Bhanpuri and Reynolds, 2003). The event dropout is one way to measure dropout to determine the percentage of students that dropout in a single year without completing a level or grade (Bhanpuri and Reynolds, 2003). It is a reliable notion that determines dropout based on oneyear figure. year without completing a level or 
grade (Bhanpuri and Reynolds, 2003). It is a reliable notion that determines dropout based on one-year figure.
The status of dropout for primary level in Palpa district is shown in figure 2 . The overall dropout rate of primary level for Palpa district was 7.9 percent in 2009 (appendix 1). There is no distinct

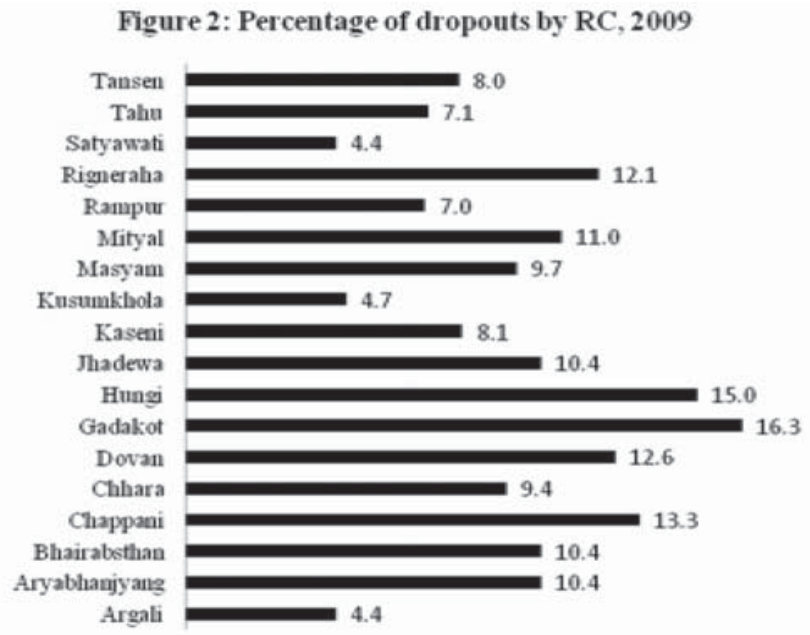

The status of dropout for primary level in Palpa district is shown in figure 2 . The overall dropout rate of primary level for Palpa district was 7.9 percent in 2009 (appendix 1). There is no distinct variation in dropout rate of boys and girls in variation in dropout rate of boys and girls in totality. However the rates vary by RC. The average national dropout rate was 12.4 percent and it was 8.1 percent for Palpa district in 2007 (DOE, 2008). This indicates the declining dropout of the district however; it is still high

\section{Table 3: Resource Centers by Dropout Rate Category}

\begin{tabular}{|l|l|}
\hline Dropout rate & Name of RC \\
\hline$<5$ & Argali, Kusumkhola, and Satyawati (3) \\
\hline $5-10$ & Chhara, Kaseni, Masyam, Rampur,Tahu and Tansen (6) \\
\hline $10-15$ & $\begin{array}{l}\text { Aryabhanjyang, Bhairabsthan, Chappani, Dovan, Jhadewa, Mityal, } \\
\text { Rigneraha (7) }\end{array}$ \\
\hline 15 \& over & Gadakot and Hungi (2) \\
\hline Total & \multicolumn{1}{|c|}{18} \\
\hline
\end{tabular}

Source: Calculated from Database, DEO, Palpa, 2009.

totality. However the rates vary by RC. The average national dropout rate was 12.4 percent and it was 8.1 percent for Palpa district in 2007 (DOE, 2008). This indicates the declining dropout of the district however; it is still high due to various reasons. Ignorance of parents, poverty, long distance between school and home, and cultural factors are responsible for this high dropout rate. due to various reasons. Ignorance of parents, poverty, long distance between school and home, and cultural factors are responsible for this high dropout rate.

The sharp variations in dropout rate can be seen across the district by RC ranging from 4.4 in Satyawati and Argali to 16.3 percent in Gadakot (Table 3). Gadakot is situated in the far-east of the district and Satyawati at another extreme position in the south-western part of the district. 
The dropout rate of Gadakot is nearly four times higher than that of Satyawati. The Gadakot area is one of the remote areas of Palpa district and is adversely affected by low development of infrastructure. Altogether 3 out of 18 RCs had low dropout rate below 5 percent. Seven out of 18 showed dropout rate in-between 10 and 15 and 6 showed in-between 5 and 10 . making children who have not mastered the curriculum and thus do not reach certain academic standards and repeat the year while their peers are promoted to the next year. A repeater is a child who has to repeat the same grade due to academic failure, insufficient examination marks to advance for the next level of instruction, age, poor attendance, or simply from lack of local educational opportunities

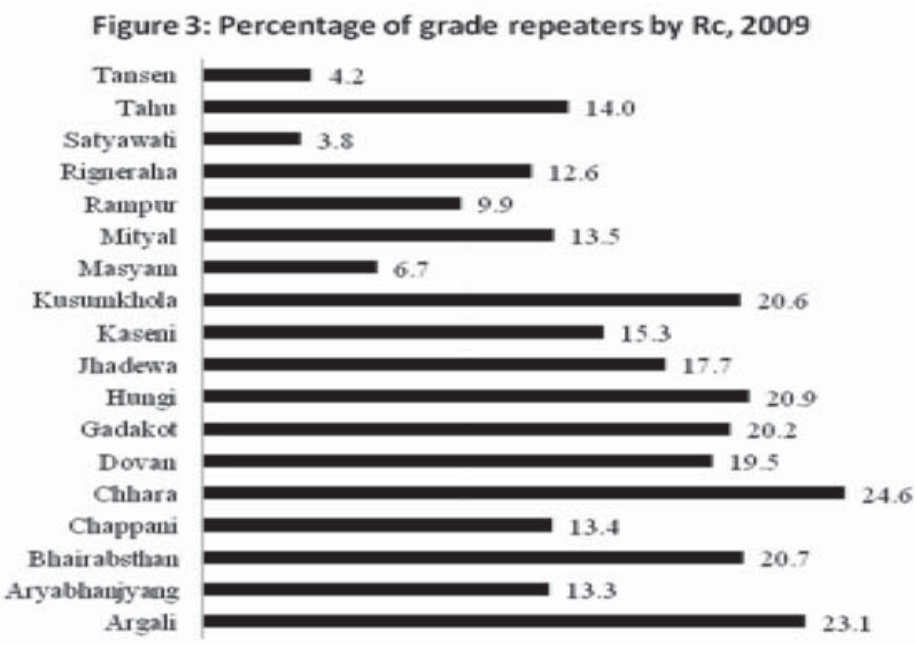

\section{Status of Grade Repetition}

Repetition rate is the powerful indicator of the performance of education and considered as one of the indicators measuring educational wastage. Repetition means retention in the same grade or level of study where the normal expectation is either promotion or completion of schooling. Brimer and Pauli (1971) has stated that "by repetition is meant a year spent by a pupil in the same grade and doing the same work as in the previous year". According to Ndaruhuse (2008) repetition is the practice of
(Eiseman, 1997). A repeater may or may not become a dropout, but there is a high probability that $\mathrm{s} /$ he will.

Figure 3 shows the scenario of grade repetition for primary level in Palpa District by resource centre. On an average the proportion of students repeating primary grades was almost 15 percent. The average repetition rate of Nepal for primary level (grade 1- 5) was 17.2 percent, and it was 20.6 for Palpa District as a whole in 2007 (DOE, 2008). The data show some improvement in the repetition rate compared to that of 2007 . However, still there is huge wastage.

Table 4

Number and distribution of $\mathrm{RC}$ by repetition rate category

\begin{tabular}{|l|l|}
\hline Repetition rate & Name of RC \\
\hline$<5$ & Satyawati and Tansen (2) \\
\hline $5-10$ & Mashyam and Rampur (2) \\
\hline $10-15$ & Aryabhanjyang, Chappani , Mityal Tahu and Rigneraaha (5) \\
\hline $15-20$ & Dovan, Jhadewa and Kaseni (3) \\
\hline $20 \&$ above & Argali, Bhairabsthan, Chhara, Gadakot, Hungi and Kushumkhola (6) \\
\hline Total & \multicolumn{1}{c|}{18} \\
\hline
\end{tabular}

Source: Calculated from Database, DEO, Palpa, 2009. 
Examination failure, poverty and the ignorance of parents are the main causes of high repetition. In many cases, especially, poor and dalit children left the schools after the distribution of scholarships and then enrolled again the next year, hoping for scholarships. They enrolled essentially for scholarships rather than simply to complete grades. Interestingly, the proportion of grade repeater of girls and boys was 14.1 and 15 percent respectively (appendix 1 ).

Intra-district variation in grade repetition was also very high, ranging from 3.8 percent in Satyawati to almost 25 percent in Chhara. Almost one-fourth of the enrolled students were grade repeaters in Chhara in 2009. More than one-third $\mathrm{RC}$ s had a high repetition rate - above 20. The proportion of RCs showing a low repetition rate (below 10) was about 20 percent.

\section{Conclusion}

Dropout and repetition are the two major indicators measuring educational wastage and the key impediments to increasing educational access and attainment. Primary education in Palpa District is characterized generally by high dropout and grade repetition but with high intradistrict variations between resource centres.
Nearly 10 percent of total students who enrolled in primary schools left before completing their grades, for different reasons. The problem of grade repetition is equally crucial. The proportion of grade repeaters in the total enrollment was almost 15 percent in the district. This represents a high wastage of resources in primary education. Failure in examination, poverty and the ignorance of the parents, as well as cultural factors, are responsible for high repetition and dropout. In many cases, especially, poor and dalit children left the schools after distribution of scholarships and get enrolled again next year hoping the same. It is one of the challenges hindering the millennium development goals of universal primary education-'quality basic education for all'.

Raising stable enrolment and reducing the dropout rate is the key to effective universal primary education. Some improvement can be seen from these data in both dropout and repetition during the last two years (as compared to 2007); however, the rate of improvement is still too low to achieve the Millennium Development goals. Emphasis should be given with a view of raising enrolment and reducing dropout and grade repetition by raising awareness of parents.

\section{References}

Acharya, S. (2007). Social Inclusion: Gender and Equity in Education SWAPS in South Asia (Nepal Case Study), Kathmandu: UNICEF

Bhanpuri, H. and Reynolds, G. M. (2003). Understanding and Addressing the Issue of the High School Dropout Age. From http://www.ncrel.org/policy/pubs/html/second/index.html, retrieved on May 2010.

Brimer, M.A. and Pauli, L. (1971). Wastage in Education: A World Problem. Paris: UNESCO

Central Bureau of Statistics (CBS) (2002). Population of Nepal: Village Development Committee/ Municipalities, Population Census 2001. Kathmandu: National Planning Secretariat.

CERID (2001). A study on Improvement of Internal Efficiency of Primary Education. Kathmandu: CERID

Department of Education (2008). School Level Educational Statistics of Nepal: Consolidated Report2007 (2064). Kathmandu: Ministry of Education and Sports.

District Education Office (2009). Status Report 2009. Tansen: DEO, Palpa.

District Education Office (2009). School Mapping Database 2009. Tansen: DEO, Palpa.

Eiseman, T. O. (1997). Reducing Repetition: Issues and Strategies. Paris: UNESCO 
Government of Nepal (2006). National Demographic and Health Survey. Kathmandu: Ministry of Health and Population.

Government of Nepal (2009). School Sector Reform Plan 2009-2015. Kathmandu: Ministry of Education.

Karki, Vishnu (2009). Primary School Dropout in Nepal: Antecedents and Subsequent Activities. Retrieved on May 23, 2010, from http://www.amajon.com.

Tomasevski, K. (2004). Manual on Rights-Based Education: Global Human Rights Requirements Made Simple. Bankok: Asia and Pacific Regional Bureau for Education, UNESCO.

United Nations (2008). The Millennium Development Goals Report 2008. New York: United Nations.

UNDP (2004), Nepal Human Development Report 2004: Empowerment and Poverty Reduction. Kathmandu: UNDP.

UNESCO (1984). The Drop-out Problem in Primary Education: Some Case Studies. Bankok: UNESCO Regional Office for Education in Asia and the Pacific.

UNICEF (2006). Situation of Children and Women in Nepal. Kathmandu: United Nations Children's Fund.

United States General Accounting Office (GAO) (2002). School Dropouts: Education Could Play a Stronger Role in Identifying and Dissemination Promising Prevention Strategies. Washington DC: GAO

\section{Appendix 1: Percentage of Dropout and Grade Repeaters by RC, 2009}

\begin{tabular}{|l|r|r|r|r|r|r|}
\hline \multirow{2}{*}{ RC } & \multicolumn{3}{|c|}{ Dropout } & \multicolumn{3}{c|}{ Repetition } \\
\cline { 2 - 7 } & \multicolumn{1}{|c}{ Girls } & \multicolumn{1}{l}{ Boys } & \multicolumn{1}{l}{ Total } & \multicolumn{1}{l}{ Girls } & \multicolumn{1}{l|}{ Boys } & \multicolumn{1}{l|}{ Total } \\
\hline Argali & 4.6 & 4.1 & 4.4 & 21.4 & 24.8 & 23.1 \\
\hline Aryabhanjyang & 11.3 & 9.3 & 10.4 & 11.9 & 14.9 & 13.3 \\
\hline Bhairabsthan & 8.7 & 12.2 & 10.4 & 20.2 & 21.5 & 20.7 \\
\hline Chappani & 12.3 & 14.2 & 13.3 & 11.3 & 15.5 & 13.4 \\
\hline Chhara & 9.9 & 9.0 & 9.4 & 23.8 & 25.4 & 24.6 \\
\hline Dovan & 11.3 & 14.0 & 12.6 & 18.6 & 20.4 & 19.5 \\
\hline Gadakot & 15.6 & 17.2 & 16.3 & 19.5 & 21.1 & 20.2 \\
\hline Hungi & 17.8 & 11.8 & 15.0 & 20.2 & 21.7 & 20.9 \\
\hline Jhadewa & 9.9 & 10.8 & 10.4 & 18.3 & 17.1 & 17.7 \\
\hline Kaseni & 7.8 & 8.4 & 8.1 & 15.2 & 15.5 & 15.3 \\
\hline Kusumkhola & 0.9 & 8.4 & 4.7 & 21.8 & 19.5 & 20.6 \\
\hline Masyam & 9.2 & 10.2 & 9.7 & 5.8 & 7.6 & 6.7 \\
\hline Mityal & 11.3 & 10.6 & 11.0 & 13.1 & 13.8 & 13.5 \\
\hline Rampur & 7.0 & 7.1 & 7.0 & 9.7 & 10.1 & 9.9 \\
\hline Rigneraha & 11.7 & 12.5 & 12.1 & 11.7 & 13.4 & 12.6 \\
\hline Satyawati & 4.8 & 4.1 & 4.4 & 4.4 & 3.2 & 3.8 \\
\hline Tahu & 6.2 & 7.9 & 7.1 & 13 & 14.9 & 14 \\
\hline Tansen & 9.6 & 7.4 & 8.0 & 3.8 & 4.5 & 4.2 \\
\hline Total & 9.7 & 9.7 & 14.1 & 15.0 & 14.6 \\
\hline Source: DE & & & & &
\end{tabular}

